\title{
ANALISIS PELAKSANAAN SISTEM PENGENDALIAN INTERNAL PADA INSPEKTORAT KABUPATEN MINAHASA UTARA
}

\author{
Octaviani M. Kapoh ${ }^{1}$, Ventje Ilat ${ }^{2}$, Jessy D.L Warongan ${ }^{3}$ \\ 1,2,3 Jurusan Akuntansi, Fakultas Ekonomi dan Bisnis, Universitas Sam Ratulangi, Jl. Kampus Bahu, Manado, \\ 95115, Indonesia \\ E-mail : vinnyoctaviany@gmail.com
}

\begin{abstract}
Every organization, whether private or government, is obliged to carry out control activities, as one of the efforts made in achieving organizational goals that have been established. Related to the government sector in Indonesia, the current approach of internal control system is the Sistem Pengendalian Intern Pemerintah (SPIP) covering environmental elements of control, risk assessment, control activities, information and communication, and monitoring. The object of this research is Inspektorat Kabupaten Minahasa Utara. As the research method used is descriptive qualitative. That results of this study can be concluded that the implementation of internal control system in the Inspektorat Kabupaten Minahasa Utara has been in accordance with the elements in the Internal Control System that has been established by the government based on Government Regulation No. 60 of 2008, so as to show the achievment of Inspektorat Kabupaten Minahasa Utara performance in 2016 has increased and can be said to be effective.
\end{abstract}

Keywords: Government Internal Control System, Control Environment, Risk Assessment, Control Activities, Information and Communication, Monitoring

\section{PENDAHULUAN}

Dalam mewujudkan good governance, pemerintah perlu memiliki dan melaksanakan sistem pengendalian dalam organisasi guna mendapatkan kinerja aparat pemerintah yang baik. Terkait sektor pemerintahan di Indonesia, pendekatan terkini dari sistem pengendalian intern adalah Sistem Pengendalian Intern Pemerintah (SPIP) yang didasarkan pada Peraturan Pemerintah Nomor 60 Tahun 2008. Dengan adanya pengendalian internal pada suatu organisasi, maka seluruh proses kegiatan dalam rangka memberikan keyakinan yang memadai atas tercapainya tujuan organisasi melalui kegiatan yang efektif dan efisien akan terealisasi, sehingga good governance dapat terwujud. Oleh karena itu, untuk memperbaiki kinerja pemerintah, pimpinan dari setiap instansi baik di pusat maupun di daerah perlu membangun dan menerapkan sistem pengendalian manajemen secara internal yang memadai atas penyelenggaraan kegiatan pemerintahan.

Inspektorat daerah melaksanakan kegiatan audit guna mendukung fungsi pengawasan internal yang ada dalam pemerintahan daerah. Namun pada kenyataanya, dewasa ini banyak fenomena-fenomena yang terjadi menimbulkan persepsi bahwa Inspektorat sebagai auditor internal pemerintah belum optimal melaksanakan tugas dan fungsinya sesuai dengan standar dan pedoman yang telah ditetapkan. Hal ini dibuktikan dengan maraknya terjadi penyimpangan yang melibatkan aparatur pemerintah dalam instansi-instansi yang berada dalam cakupan pengawasan Inspektorat. Padahal seharusnya dengan adanya Inspektorat di wilayah kabupaten/kota, penyimpangan bisa terdeteksi sejak dini sehingga dapat mencegah 
bahkan mengurangi penyimpangan. Adanya fenomena ini menunjukkan bahwa kinerja aparat Inspektorat belum efektif dan masih relatif rendah.

Dalam upaya mewujudkan visi organisasi, Inspektorat Kabupaten Minahasa Utara perlu melaksanakan pengendalian internal. Dan dalam pelaksanaannya pasti Inspektorat Kabupaten Minahasa Utara sendiri selalu diperhadapkan dengan berbagai kendala atau permasalahan, salah satunya adalah dengan belum maksimalnya sistem pengendalian internal yang diterapkan sehingga hal tersebut bisa menghambat pencapaian tujuan organisasi.

Berdasarkan informasi yang diperoleh dari lapangan, Inspektorat Kabupaten Minahasa Utara ternyata tidak terlalu memperhatikan latar pendidikan pegawainya, sehingga tidak seluruh auditor dan pejabat P2UPD yang melakukan tugas pokok pengawasan berlatar belakang pendidikan ekonomi, khususnya akuntansi.

Atas dasar uraian latar belakang masalah diatas, maka penulis tertarik melakukan penelitian dengan judul "Analisis Pelaksanaan Sistem Pengendalian Internal pada Inspektorat Kabupaten MinahasaUtara".

Tujuan penelitian ini adalah untuk mengetahui kesesuaian pelaksanaan sistem pengendalian internal yang dilakukan oleh Inspektorat Kabupaten Minahasa Utara berdasarkan unsur-unsur pengendalian internal.

\section{TINJAUAN PUSTAKA}

\subsection{Akuntansi, Akuntansi Sektor Publik dan Akuntansi Pemerintahan}

Menurut Sujarweni (2015:1) akuntansi adalah suatu aktivitas jasa yang terdiri dari mencatat, mengklasifikasikan, dan melaporkan kejadian atau transaksi ekonomi yang akhirnya akan menghasilkan suatu informasi keuangan yang akan dibutuhkan oleh pihakpihak tertentu untuk pengambilan keputusan. Akuntansi sangat diperlukan pada setiap jenis organisasi, termasuk organisasi sektor publik. Organisasi sektor publik merupakan organisasi yang bergerak dalam bidang pelayanan publik dan penyelenggaraan negara dalam pelaksanaan konstitusi dan pada umumnya berupa lembaga negara atau pemerintahan atau organisasi yang memiliki keterkaitan dengan keuangan negara.

Akuntansi sektor publik dapat didefinisikan sebagai aktivitas jasa yang terdiri dari mencatat, mengklasifikasikan dan melaporkan kejadian atau transaksi ekonomi yang akhirnya akan menghasilkan suatu informasi keuangan yang akan dibutuhkan oleh pihak-pihak tertentu sebagai pengambilan keputusan yang diterapkan pada pengelolaan dana publik di lembagalembaga tinggi negara dan departemen-departemen dibawahnya (Sujarweni, 2015:1).

Ada beberapa jenis akuntansi yang merupakan bagian dari akuntansi sektor publik, salah satunya adalah akuntansi pemerintahan. Menurut Deddi, dkk. (2012:1) akuntansi pemerintahan adalah aplikasi akuntansi di bidang keuangan negara, khususnya pada tahapan pelaksanaan anggaran, termasuk segala pengaruh yang ditimbulkannya, baik yang bersifat seketika maupun yang lebih permanen pada semua tingkatan dan unit pemerintahan.

\subsection{Sistem Pengendalian Internal}

Menurut Matamande, et al. (2012), pengertian sistem pengendalian intern adalah menempatkan satu set kebijakan organisasi dan disetujui proses pengendalian intern dibuat oleh manajemen suatu organisasi untuk pura-pura mencapai tujuan utama manajemen untuk memastikan bahwa bisnis beroperasi sempurna.

\subsubsection{Tujuan Sistem Pengendalian Internal}

Thahjono sebagaimana dalam Dera (2016) menyatakan bahwa pengendalian intern administrasi mempunyai tujuan meningkatkan efisiensi operasi dan meyakinkan bahwa kebijakan manajemen ditaati karyawan. Sedangkan pengendalian intern akuntansi 
mempunyai tujuan agar harta milik perusahan bisa terjaga dari kecurangan dan agar catatancatatan akuntansi dapat dipercaya. Biasanya manajemen memiliki tiga tujuan umum dalam merancang sistem pengendalian intern yang efektif yaitu:

1. Rehabilitas Pelaporan Keuangan

2. Efisiensi dan Efektifitas Operasi

3. Ketaatan pada Hukum Dan Peraturan

\subsubsection{Prinsip Dasar Pengendalian Internal}

Menurut Sanyoto sebagaimana ditulis dalam Binanggal (2016) menyatakan bahwa ada beberapa asumsi dasar yang perlu dipahami mengenai pengendalian internal bagi suatu entitas oragnisasi atau perusahan;

a. Sistem pengendalian intern merupakan management responsibility

b. Top manajemen bertanggung jawab menyusun sistem pengendalian intern

c. Sistem pengendalian intern seharusnya bersifat generic, mendasar, dan dapat diterapkan pada semua perusahaan pada umumnya

d. Sifat sistem pengendalian intern adalah reasonable assurance

e. Sistem pengendalian intern mempunyai keterbatasan-keterbatasan atau constraints

f. Sistem pengendalian intern harus selalu dan terus menerus dievaluasi, diperbaiki, disesuaikan dengan perkembangan kondisi dan teknologi.

\subsubsection{Keterbatasan Sistem Pengendalian Internal}

Hery (2016:146) Sebuah sistem pengendalian yang baik akan dapat menjadi tidak efektif oleh karena adanya karyawan yang kelelahan, ceroboh atau bersikap acuh tak acuh. Demikian juga halnya dengan kolusi, hal ini akan dapat secara signifikasn mengurangi keefektifan sebuah sistem dan mengeliminasi proteksi yang ditawarkan dari pemisahan tugas.

\subsection{Sistem Pengendalian Internal Pemerintah}

Menurut Hoesada (2016:181) Sistem Pengendalian Intern Pemerintah (SPIP) secara konseptual mengadopsi framework sistem pengendalian intern yang dirilis tahun 1992 oleh Committee of Sponsoring Organization "COSO framework". Sistem Pengendalian Internal Pemerintah (SPIP) adalah sistem pengendalian intern yang diselenggarakan secara menyeluruh di lingkungan pemerintah pusat dan pemerintah daerah.

\subsubsection{Tujuan Sistem Pengendalian Internal Pemerintah}

Adapun tujuan dari SPIP menurut Peraturan Pemerintah Nomor 60 Tahun 2008 pasal 2 (ayat 3), antara lain :

1. untuk memberikan keyakinan yang memadai bagi tercapainya efektivitas dan efisiensi pencapaian tujuan penyelenggaraan pemerintahan negara,

2. keandalan pelaporan keuangan,

3. pengamanan aset negara, dan

4. ketaatan terhadap peraturan perundang-undangan.

\subsubsection{Unsur Sistem Pengendalian Internal Pemerintah (SPIP)}

Menurut UU No. 60 Tahun 2008 Pasal 3 Tentang Sistem Pengendalian Intern Pemerintah menyebutkan bahwan sistem pengendalian intern pemerintah terdiri atas unsur sebagai berikut :

1. Lingkungan Pengendalian

2. Kegiatan Pengendalian

3. Penilaian Risiko

4. Informasi dan Komunikasi

5. Pemantauan 


\subsection{Konsep Efektivitas}

Menurut Mahsun (2006:182) efektivitas (hasil guna) merupakan hubungan antara keluaran dengan tujuan atau sasaran yang harus dicapai. Pengertian efektivitas ini pada dasarnya berhubungan dengan pencapaian tujuan atau target kebijakan. Kegiatan operasional dikatakan efektif apabila proses kegiatan tersebut mencapai tujuan dan sasaran akhir kebijakan (spending wisely).

Sedangkan pengertian efektivitas menurut Schermerhorn, Jr \& John, R (1986:35) adalah sebagai berikut: "Efektivitas adalah pencapaian target output yang diukur dengan cara membandingkan output anggaran atau seharusnya (OA) dengan output realisasi atau sesungguhnya $(\mathrm{OS})$, jika $(\mathrm{OS})>(\mathrm{OA})$ disebut efektif ". Berdasarkan hal tersebut maka untuk mencari tingkat efektivitas dapat digunakan rumus sebagai berikut:

$$
\text { Efektivitas }=\text { Output Aktual } / \text { Output Target } \geq 1
$$

a. Jika output aktual berbanding output yang ditargetkan lebih besar atau sama dengan 1 (satu), maka akan tercapai efektivitas.

b. Jika output aktual berbanding output yang ditargetkan kurang daripada 1 (satu), maka efektivitas tidak tercapai.

Ndraha (2005:163) mengemukakan bahwa efektivitas (effectiveness) yang didefinisikan secara abstrak sebagai tingkat pencapaian tujuan, yang dapat diukur dengan rumus sebagai berikut :

\subsection{Penelitian Terdahuu}

$$
\text { Efektivitas }=\text { Realisasi } / \text { Target }
$$

Ismani, et al. (2014) dalam penelitian yang berjudul Implementasi sistem pengendalian intern pemerintah di Universitas Negeri Yogyakarta. Hasil penelitian memberikan kesimpulan bahwa implementasi unsur-unsur Sistem Pengendalian Intern Pemerintah di UNY sudah berjalan dengan baik.

Hamidah (2014) dalam penelitian yang berjudul Pengaruh pelaksanaan sistem pengendalian intern pemerintah dan sumber daya manusia terhadap pengamanan aset negara. Hasil penelitian menunjukkan terdapat pengaruh yang signifikan dan positif penerapan SPIP dan sumber daya manusia terhadap pengamanan aset negara. Dimana semakin baik penerapan SPIP dan sumber daya manusia maka pengamanan aset negara pun akan semakin baik.

\section{METODE PENELITIAN}

\subsection{Jenis dan Sumber Data}

Data yang digunakan dalam penelitian ini adalah data kualitatif. Data kualitatif yang dibutuhkan dalam penelitian ini adalah Sistem Pengendalian Internal Pemerintah dari Inspektorat pada Pemerintahan Kabupaten Minahasa Utara. Sumber data yang digunakan dalam penelitian ini adalah data primer dan data sekunder. Data primer yang dibutuhkan merupakan data olahan dan diperoleh langsung dari Inspektorat, dan data sekunder merupakan data yang diambil dari bahan pustaka.

\subsection{Metode Analisis}

Metode yang digunakan dalam penelitian ini adalah analisis data deskriptif kualitatif, yaitu penulis mendeskripsikan semua data yang diperoleh dan menginterpretasikan dengan kata-kata atau bersifat nonnumerik. Menurut Miles and Huberman dalam Sugiyono (2012:91) mengemukakan bahwa aktivitas dalam analisis data kualitatif dilakukan secara interaktif dan berlangsung secara terus menerus pada setiap tahapan penelitian sehingga 
sampai tuntas, dan datanya sampai jenuh. Aktivitas dalam analisis data ini diawali dari pengumpulan data, selanjutnya data-data yang diperoleh dari hasil wawancara, observasi dan juga dokumentasi tersebut kemudian dikelompokkan berdasarkan tingkat keeratannya dengan permasalahan yang diangkat oleh penulis, setelah itu penulis menyajikan data yang telah di kelompokkan tersebut dan menarik kesimpulan.

\section{HASIL ANALISIS DAN PEMBAHASAN}

\subsection{Hasil Analisis}

Berdasarkan penelitian yang dilakukan dapat diketahui bahwa pencapaian sasaran strategis yang terdiri dari 5 (lima) indikator kinerja Inspektorat Kabupaten Minahasa Utara pada tahun 2016 secara keseluruhan telah berjalan dengan cukup baik karena dimana 4 (empat) indikator telah mencapai target yang telah ditetapkan oleh Kementerian Pendayagunaan Aparatur Negara dan Reformasi. Malahan 3 (tiga) indikator diantaranya melebihi pencapaian yang direncanakan. Pengukuran capaian kinerja dari sasaran strategis Inspektorat Kabupaten Minahasa Utara yang telah ditetapkan pemerintah, dilakukan dengan membandingkan antara realisasi kinerja dengan target kinerja, sehingga alat ukur yang digunakan untuk mengetahui tingkat efektivitas organisasi yang ada di Inspektorat Kabupaten Minahasa Utara, sesuai dengan teori dari Ndraha (2005:163) dirumuskan dengan perbandingan rasio antara realisasi dengan target.

$$
\text { Efektivitas }=\text { Realisasi / Target }
$$

Dengan menggunakan rasio perbandingan diatas, dapat diketahui tingkat efektivitas pencapaian kinerja Inspektorat Kabupaten Minahasa Utara sebagaimana ditampilkan pada Tabel 1 berikut ini.

Tabel. 1

\section{Efektivitas Pencapaian Kinerja terhadap 5 (lima) Indikator dari Sasaran Strategis Peningkatan Kualitas Kinerja Pengawasan Internal yang dilakukan Inspektorat Kabupaten Minahasa Utara Tahun 2016}

\begin{tabular}{|c|c|c|c|c|c|}
\hline No. & Indikator & Target & Realisasi & Pencapaian & Penilaian \\
\hline 1 & $\begin{array}{c}\text { Prosentase rekomendasi tindak } \\
\text { lanjut hasil pemeriksaan }\end{array}$ & $20 \%$ & $8,23 \%$ & $\begin{array}{c}41,15 \% \\
(0,4115)\end{array}$ & Tidak Efektif \\
\hline 2 & $\begin{array}{c}\text { Prosentase SKPD/unit kerja yang } \\
\text { tidak mempunyai temuan } \\
\text { penyimpangan pengelolaan } \\
\text { keuangan yang material }\end{array}$ & $80 \%$ & $86,48 \%$ & $\begin{array}{c}108,1 \% \\
(1,0810)\end{array}$ & Efektif \\
\hline 3 & $\begin{array}{c}\text { Prosentase SKPD/unit kerja yang } \\
\text { tidak mempunyai temuan } \\
\text { penyimpangan pengelolaan aset } \\
\text { yang material }\end{array}$ & $80 \%$ & $80 \%$ & $\begin{array}{c}100 \% \\
(1,0000)\end{array}$ & Efektif \\
\hline 4 & $\begin{array}{c}\text { Prosentase SKPD yang hasil } \\
\text { penilaian LAKIPnya meningkat }\end{array}$ & $50 \%$ & $84,37 \%$ & $\begin{array}{c}168,74 \% \\
(1,6874)\end{array}$ & Efektif \\
\hline 5 & $\begin{array}{c}\text { Prosentase Desa yang tidak } \\
\text { mempunyai temuan } \\
\text { penyimpangan pengelolaan } \\
\text { keuangan yang material }\end{array}$ & $70 \%$ & $84,09 \%$ & $\begin{array}{c}120,13 \% \\
(1,2013)\end{array}$ & Efektif \\
\hline
\end{tabular}

Sumber : Data Olahan 2016 
Dari perhitungan efektivitas pencapaian kinerja Inspektorat Kabupaten Minahasa Utara, dapat diberikan penilaian berdasarkan kriteria penilaian menurut teori Schermerhorn, Jr \& John, R (1986:35) yaitu sebagai berikut :

a. Jika output aktual berbanding output yang ditargetkan lebih dari atau sama dengan 1 (satu), maka akan tercapai efektivitas.

b. Jika output aktual berbanding output yang ditargetkan kurang dari 1 (satu), maka efektivitas tidak tercapai.

Secara keseluruhan Pencapaian Kinerja terhadap 5 (lima) Indikator dari Sasaran Strategis Peningkatan Kualitas Kinerja Pengawasan Internal yang dilakukan Inspektorat Kabupaten Minahasa Utara Tahun 2016 hasilnya lebih dari atau sama dengan 1 (satu), sehingga hal ini menunjukan bahwa pencapaian kinerja Inspektorat Kabupaten Minahasa Utara telah efektif.

Keberhasilan pencapaian organisasi tersebut menjadi salah satu bukti bahwa Inspektorat Kabupaten Minahasa Utara telah melaksanakan sistem pengendalian internal dengan baik dalam pelaksanaan tugas dan fungsinya. Unsur-unsur dalam SPIP yang diterapkan oleh Inspektorat Kabupaten Minahasa Utara memang berperan penting terhadap efektivitas pencapaian kinerja organisasi. Dengan adanya pengendalian intern yang baik maka kecurangan dalam kegiatan pengawasan Inspektorat Kabupaten Minahasa Utara dapat dihindari.

\subsubsection{Analisis Sistem Pengendalian Intern Pemerintah (SPIP) pada Inspektorat Kabupaten Minahasa Utara}

Berdasarkan penelitian yang dilakukan dan telah diuraikan maka penulis menarik hasil analisis sebagai berikut :

1. Lingkungan Pengendalian

Kondisi lingkungan pengendalian Inspektorat Kabupaten Minahasa Utara secara umum sudah memadai, karena Inspektorat Kabupaten Minahasa Utara telah menciptakan dan memelihara lingkungan pengendalian yang menimbulkan perilaku positif dan kondusif untuk penerapan sistem pengendalian intern dalam lingkungan kerjanya, melalui penetapan dan penerapan aturan mengenai standar perilaku etis yang memberikan kerangka perilaku bagi seluruh pegawai. Adapun komitmen terhadap kompetensi terlihat dari pelaksanaan setiap kegiatan yang ada di Inspektorat Kabupaten Minahasa Utara yang dilakukan oleh pegawai-pegawai yang berkompeten dalam bidangnya masing-masing. Hal tersebut sesuai dengan Mulyadi (2014:164) jika perusahaan memiliki karyawan yang kompeten dan jujur, unsur pengendalian yang lain dapat dikurangi sampai batas yang minimum dan perusahaan tetap mampu menghasilkan pertanggung jawaban keuangan yang dapat diandalkan. Maka sebagai upaya dalam mempertahankan serta meningkatkan kompetensi setiap pegawai, Inspektorat Kabupaten Minahasa Utara rutin mengikutsertakan pegawainya dalam kegiatan Bimbingan Teknis (bimtek), pendidikan dan pelatihan-pelatihan (diklat) berjenjang.

Kepemimpinan yang kondusif di Inspektorat Kabupaten Minahasa Utara juga sudah mencerminkan sistem pengendalian yang baik, dimana pimpinan selalu memberikan arahan, motivasi serta teladan langsung kepada seluruh pegawai. Selain itu, pimpinan juga sangat memperhatikan kesejahteraan pegawai, selalu mengevaluasi kinerja setiap pegawai, dan menjalin interaksi aktif dengan seluruh bawahannya. Pembentukan struktur organisasi serta metode pendelegasian wewenang dan tanggung jawab yang ada di Inspektorat Kabupaten Minahasa Utara telah menggambarkan sistem pengendalian intern yang baik. Hal ini dapat dilihat dari adanya pembagian tugas yang telah secara jelas dikomunikasikan kepada setiap pegawai. Perwujudan peran aparat pengawasan intern pemerintah yang efektif juga berjalan dengan baik, terlihat dari rutinitas Inspektorat Kabupaten Minahasa Utara yang selalu 
membuat Laporan Hasil Pengawasan (LHP) serta menyampaikannya kepada pimpinan instansi pemerintah yang diawasi dan juga kepada Bupati. Selain itu Inspektorat Kabupaten Minahasa Utara juga memiliki hubungan kerja yang baik dengan instansi pemerintah yang mengelola anggaran, akuntansi dan perbendaharaan. Maka kesemua hal tersebut mengindikasikan bahwa nilai-nilai lingkungan pengendalian yang baik telah terinternalisasi dan terimplementasi dengan baik di Inspektorat Kabupaten Minahasa Utara.

2. Penilaian Risiko

Dalam melaksanakan penilaian risiko, Inspektur telah melakukan indentifikasi, menganalisis risiko dan menentukan tindakan yang tepat untuk menghadapi risiko-risiko yang dapat menghambat pencapaian visi dan misi Inspektorat Kabupaten Minahasa Utara. Hal ini telah sesuai dengan PP No. 60 Tahun 2008 tentang Sistem Pengendalian Intern Pemerintah (SPIP), sehingga dapat dikatakan penilaian resiko pada Inspektorat Kabupaten Minahasa Utara secara umum telah baik. Namun meskipun Inspektorat Kabupaten Minahasa Utara telah melakukan penilaian risiko, masih saja terdapat resiko yang harus dihadapi.

3. Kegiatan Pengendalian

Sesuai dengan unsur-unsur pengendalian intern PP No. 60 Tahun 2008, kegiatan pengendalian adalah kebijakan dan prosedur yang dapat membantu memastikan dilaksanakannya arahan pimpinan Instansi Pemerintah untuk mengurangi risiko yang telah diidentifikasi selama proses penilaian risiko. Inspektorat Kabupaten Minahasa Utara telah efektif menerapkan unsur pengendalian ini. Pimpinan telah mengidentifikasi tindakan dan kegiatan pengendalian yang diperlukan untuk menangani setiap risiko dan memberikan arahan penerapannya.

Terlihat juga ada pemisahan fungsi yang dilakukan berdasarkan tugas pokok dan fungsi sesuai Peraturan Bupati Kabupaten Minahasa Utara Nomor 72 Tahun 2016. Kegiatan pengendalian secara berkala dievaluasi untuk memastikan bahwa kegiatan-kegiatan tersebut masih sesuai dan berfungsi sebagaimana diharapkan.

4. Informasi dan Komunikasi

Demi menunjang sistem pengendalian intern dan manajemen yang sehat, Inspektorat Kabupaten Minahasa Utara telah menerapkan unsur informasi yang tepat dan komunikasi secara baik, melalui berbagai sarana komunikasi baik berupa buku pedoman kebijakan dan petunjuk teknis, surat edaran, memorandum, papan pengumuman, situs internet dan e-mail, maupun berkomunikasi lisan secara langsung. Inspektorat Kabupaten Minahasa Utara juga memiliki saluran komunikasi yang terbuka dan efektif dengan masyarakat, rekanan, serta kelompok lainnya yang bisa memberikan masukan signifikan terhadap kualitas pelayanan Inspektorat.

5. Pemantauan

Pemantauan pada Inspektorat Kabupaten Minahasa Utara sudah berjalan baik, hal ini ditunjukkan dari model-model pemantauan dari pemantauan berkelanjutan, pemantauan terpisah dan penyelesaian tindak lanjut. Adapun wujud pemantauan berupa evaluasi atas perbaikan/pembuatan serta pelaksanaan kebijakan dan prosedur dalam rangka menyelesaikan permasalahan dan mengatasi risiko, untuk mendapatkan informasi. Ringkasan mengenai pelaksanaan setiap unsur yang ada dalam Sistem Pengendalian Intern Pemerintah (SPIP), dapat dilihat pada Tabel 2 berikut. 
Tabel. 2

Pelaksanaan Sistem Pengendalian Intern Pemerintah (SPIP) di Inspektorat Kabupaten Minahasa Utara

\begin{tabular}{|c|c|c|c|c|}
\hline No. & Unsur SPIP & $\begin{array}{l}\text { Pelaksanaan } \\
\text { Lapangan }\end{array}$ & $\begin{array}{l}\text { Dasar } \\
\text { Aturan }\end{array}$ & $\begin{array}{c}\text { Keterangan Dasar } \\
\text { Aturan }\end{array}$ \\
\hline 1 & Lingkungan Pengendalian: & & & \\
\hline & - Integritas \& Nilai Etika & $\checkmark$ & $\checkmark$ & $\begin{array}{c}\text { PP No. } 53 \text { Tahun } 2010 \\
\text { dan Kode Etik APIP } \\
\text { (PER/04/M.PAN/03/2008) } \\
\end{array}$ \\
\hline & - Komitmen terhadap Kompetensi & $\checkmark$ & & \\
\hline & - Kepemimpinan yang Kondusif & $\checkmark$ & & \\
\hline & - Struktur Organisasi & $\checkmark$ & $\checkmark$ & PERDA No. 5 Tahun 2016 \\
\hline & $\begin{array}{l}\text { - Pendelegasian Wewenang \& } \\
\text { Tanggung Jawab }\end{array}$ & $\checkmark$ & $\checkmark$ & $\begin{array}{c}\text { PERBUB No. } 72 \text { Tahun } \\
2016\end{array}$ \\
\hline & $\begin{array}{l}\text { - Kebijakan \& Praktik Pembinaan } \\
\text { SDM }\end{array}$ & $\checkmark$ & & \\
\hline & $\begin{array}{l}\text { - Perwujudan Peran Aparat } \\
\text { Pengawasan Intern Pemerintah yang } \\
\text { Efektif }\end{array}$ & $\checkmark$ & & \\
\hline & $\begin{array}{l}\text { - Hubungan Kerja yang Baik dengan } \\
\text { Instansi Pemerintah Terkait }\end{array}$ & $\checkmark$ & & \\
\hline 2 & Penilaian Risiko & $\checkmark$ & $\checkmark$ & SOP \\
\hline 3 & Kegiatan Pengendalian & $\checkmark$ & $\checkmark$ & $\begin{array}{l}\text { PERMENDAGRI No. } 17 \\
\text { Tahun } 2007 \text { dan PERBUB } \\
\text { No. } 72 \text { Tahun } 2016 \\
\end{array}$ \\
\hline 4 & Informasi \& Komunikasi & $\checkmark$ & & \\
\hline 5 & Pemantauan & $\checkmark$ & & \\
\hline
\end{tabular}

\section{Sumber : Data Olahan 2016}

Menurut Agustina (2016) apabila kelima faktor tersebut dilakukan dengan baik oleh setiap elemen pemerintah maka tujuan pemerintah akan tercapai dengan maksimal. Maka dengan menerapkan unsur - unsur pengendalian intern tersebut secara efektif, Inspektorat Kabupaten Minahasa Utara juga bisa mencapai tujuannya secara efisien dan efektif, melaporkan pengelolaan keuangan negara secara andal, mengamankan aset negara dengan baik, serta mendorong ketaatan terhadap peraturan perundang-undangan. Hasil yang diperoleh dalam pengendalian internal pada Inspektorat Kabupaten Minahasa Utara adalah sebagai berikut :

1. Efektivitas dan Efisiensi

Inspektorat Kabupaten Minahasa Utara telah menerapkan dan menjalankan sistem pengendalian internal sesuai dengan Peraturan Pemerintah Nomor 60 Tahun 2008, sehingga pencapaian tujuan penyelenggaraan pemerintah daerah yang dilakukan Inspektorat Kabupaten Minahasa Utara dapat dikatakan telah efektif.

2. Keandalan Laporan Keuangan

Inspektorat Kabupaten Minahasa Utara menyelenggarakan akuntansi pemerintahan dan anggaran melalui penyusunan laporan keuangan secara berkala setiap bulannya serta secara andal dengan berpedoman pada prinsip akuntansi yang berlaku umum, dan di akhir tahun melaksanakan evaluasi kinerja dengan penyusunan LAKIP SKPD. Selain itu, peran Inspektorat Kabupaten Minahasa Utara sebagai lembaga teknis daerah yang 
mempunyai tugas membantu Bupati dalam penyelenggaraan pemerintahan daerah di bidang pengawasan umum, bisa dikatakan berhasil khususnya dalam peningkatan kualitas laporan keuangan daerah. Karena berdasarkan hasil pemeriksaan BPK terhadap laporan keuangan dari pemerintah daerah Kabupaten Minahasa Utara, opini audit Wajar Tanpa Pengecualian (WTP) selama 2 (dua) tahun berturut-turut bisa diperoleh. Keberhasilan tersebut dapat tercapai karena Inspektorat Kabupaten Minahasa Utara selalu menerapkan pengendalian intern dalam pelaksanaan tugas dan fungsinya.

3. Pengamanan Aset Daerah

Inspektorat Kabupaten Minahasa Utara telah berupaya mengamankan aset daerah. Terlihat dari pengendalian akses ke aset yang berisiko hilang, dicuri, rusak, atau digunakan tanpa hak seperti perlengkapan, persediaan, dan peralatan, secara fisik telah diamankan.

4. Ketaatan terhadap Peraturan Perundang-Undangan

Inspektorat Kabupaten Minahasa Utara selalu berupaya menaati segala peraturan dan hukum yang berlaku khusus mengenai aturan-aturan tentang kegiatan pengawasan yang telah ditetapkan, guna mencegah timbulnya sanksi. Selain itu Inspektur juga selaku pimpinan dari Inspektorat Kabupaten Minahasa Utara, sudah memberikan arahan dan teladan yang baik secara langsung terutama mengenai intergritas dan nilai etika yang dipandang penting dalam menjalankan tugas sesuai tanggung jawab dan wewenang masing-masing pegawai.

Hasil penelitian yang dilakukan oleh penulis menunjukkan bahwa penerapan Sistem Pengendalian Intern Pemerintah (SPIP) di Inspektorat Kabupaten Minahasa Utara telah dilaksanakan dengan baik, dimana Inspektorat telah menerapkan prinsip-prinsip dalam setiap unsur yang ada dalam pengendalian internal menurut Peraturan Pemerintah Nomor 60 Tahun 2008. Hal ini sejalan dengan penelitian Nasution (2016) dengan judul "Analisis Penerapan Sistem Pengendalian Intern Pemerintah (SPIP)" dan hasil sama juga ditunjukan oleh Ismani (2014) yang menunjukkan bahwa semua unsur SPIP telah diimplementasikan dengan baik dengan judul penelitian "Implementasi Sistem Pengendalian Intern Pemerintah di Universitas Negeri Yogyakarta".

Dengan menerapakan Sistem Pengendalian Intern Pemerintah (SPIP) maka pengawasan atas pengelolaan keuangan daerah dapat berjalan dengan baik serta dapat mendukung penyelenggaraan pemerintah yang efektif dan efiisien. Jadi dapat dikatakan bahwa sistem pengendalian intern pada Inspektorat Kabupaten Minahasa Utara sudah cukup optimal dalam mendukung terciptanya good governance sejalan dengan penelitian (Ristanti, $d k k$.2014).

\section{KESIMPULAN DAN SARAN}

\subsection{Kesimpulan}

Berdasarkan hasil dari penelitian yang dilaksanakan dan berdasarkan hasil dari pembahasan yang telah dikemukakan mengenai efektivitas sistem pengendalian internal pada Inspektorat Kabupaten Minahasa Utara maka penulis dapat menarik kesimpulan bahwa:

1. Secara umum sistem pengendalian internal yang diterapkan oleh Inspektorat Kabupaten Minahasa Utara sudah baik, karena penerapannya telah dilakukan sesuai dengan unsurunsur dalam Sistem Pengendalian Intern Pemerintah (SPIP) yang telah ditetapkan berdasarkan Peraturan Pemerintah Nomor 60 Tahun 2008.

2. Secara umum Pencapaian Sasaran Strategis Inspektorat Kabupaten Minahasa Utara Tahun 2016 sudah efektif. 
3. Sistem dan prosedur yang ada di Inspektorat Kabupaten Minahasa Utara sudah cukup memadai, serta ditunjang dengan pegawai-pegawai yang berkompeten sehingga membuat tingkat kesalahan yang signifikan atas pengendalian pengawasan dapat diatasi dengan cepat, namun jumlah pegawai di Inspektorat Kabupaten Minahasa Utara belum ideal sehingga mengakibatkan pelaksanaan tugas belum sepenuhnya berjalan efisien.

\subsection{Saran}

Adapun beberapa saran yang dapat penulis berikan terkait dengan hasil penelitian dan pembahasan diatas adalah sebagai berikut:

1. Sistem pengendalian internal yang telah ada di Inspektorat Kabupaten Minahasa Utara diharapkan untuk dapat dipertahankan bahkan lebih ditingkatkan lagi sehingga efektivitas pencapaian kinerja organisasi bisa lebih optimal.

2. Agar tugas pengawasan lebih efektif, mengingat cakupan pengawasan Inspektorat Kabupaten Minahasa Utara sangat luas, sebaiknya dibuat pengusulan penambahan pegawai dengan memperhatikan kompetensi.

3. Perlu adanya perhatian serius dari pemerintah daerah terkait dengan kuantitas sumber daya manusia serta ketersediaan sarana dan prasarana penunjang yang ada di Inspektorat Kabupaten Minahasa Utara, seperti penambahan pegawai, fasilitas bangunan/gudang untuk dokumen/barang, serta pengadaan komputer dan jaringan secara memadai, sehingga dapat memaksimalkan fungsi pengawasan yang dilakukan.

4. Diharapkan pimpinan daerah yakni Bupati Minahasa Utara dapat terus menjaga serta meningkatkan komitmen atas pelaporan keuangan pemerintah daerah yang lebih baik sehingga terciptanya good governance.

5. Disarankan bagi peneliti lain yang akan mengadakan penelitian lanjutan dari permasalahan dalam penelitian ini agar lebih kritis dalam melakukan observasi dan evaluasi mengenai situasi serta kondisi instansi dalam penerapan sistem pengendalian internal.

\section{DAFTAR PUSTAKA}

Agustina, Gita Putri. Riharjo, Ikhsan Budi. 2016. Faktor-Faktor yang Mempengaruhi Kelemahan Pengendalian Intern Pemerintah Daerah. Jurnal Ilmu dan Riset Akuntansi. ISSN 2460-0585.Vol 5. No 4 April 2016. Universitas Slamet Riyadi Binanggal, Chansie Virji. 2016. Analisis Sistem Pengendalian Internal Piutang Pada PT. Tunas Dwipa Matra Cabang Manado. Jurnal EMBA Vol.4 No.3 September 2016. Hal 147-155.Fakultas Ekonomi dan Bisnis. Universitas Sam Ratulangi Manado

Deddi. Iswahyudi. Maulidah. 2012. Akuntansi Pemerintahan. Salemba Empat. Jakarta

Dera, Arya Pratama. Sondakh, Jullie J. Warongan, Jessy DL. 2016. Analisis Efektivitas Sistem Pengendalian Internal Piutang dan Kerugian Piutang Tak Tertagih pada PT. Surya Wenang Indah Manado.Jurnal EMBA. ISSN 2303-1174. Vol 4. No 1. Maret 2016. Hal 1498-1508. Fakultas Ekonomi dan Bisnis. Universitas Sam Ratulangi. Manado

Hamidah, Rita Triwi. 2014. Pengaruh Pelaksanaan Sistem Pengendalian Intern Pemerintah Dan Sumber Daya Manusia Terhadap Pengamanan Aset Negara (Studi Empiris Pada Kementrian Perindustrian Wilayah Jawa Sumatera). e-Journal UNP. Vol 2. No 1. Hal 3. Fakultas Ekonomi. Universitas Negeri Padang

Hoesada, Jan. 2016. Bunga Rampai Akuntansi Pemerintahan. Jakarta: Salemba Empat. Ikhtisar Hasil Pemeriksaan Semester I BPK Tahun 2015 
Ismani. Istiningrum, Andian Ari. Nugroho, Mahendra Adhi. Pustikaningsih, Adeng. 2014. Implementasi Sistem Pengendalian Intern Pemerintah di Universitas Negeri Yogyakarta. Jurnal Economia. Vol 10. No 1, April 2014. Hal 24-37. Universitas Negeri Yogyakarta

Matamande, Wilson, Nyikahadzoi Loveness. Taderera Ever, Mandimika Elinah. 2012. The Efectiveness of Internal Controls in Revenue Management: A Case Study of Zimbabwe Revenue Authority (ZIMRA) (2011-2012).1-2 Journal of Case Research in Business and Economics. University of Zimbabwe

Mahsun, Mohamad. 2006. Pengukuran Kinerja Sektor Publik. BPFE. Yogyakarta

Mulyadi. 2014. Auditing. Salemba Empat. Jakarta

Nasution, Achmad. 2016. Analisis Penerapan Sistem Pengendalian Intern Pemerintah (SPIP). e-Journal UNISRI. ISSN 2355-4223. Vol 3. No 1, Januari-Juli 2016. Hal 76, 78-79. Universitas Slamet Riyadi

Ndraha, Taliziduhu. 2005. Budaya Organisasi, Rineka Cipta. Jakarta.

Peraturan Bupati Minahasa Utara Provinsi Sulawesi Utara Nomor 72 Tahun 2016 Tentang Kedudukan, Susunan Organisasi, Tugas dan Fungsi Serta Tata Kerja Inspektorat Tipe B Kabupaten Minahasa Utara

Peraturan Pemerintah Nomor 60 Tahun 2008 Tentang Sistem Pengendalian Intern Pemerintah

Ristanti, Ni Made Asih. Sinarwati, Ni Kadek. Sujana, Edy. 2014. Pengaruh Sistem Pengendalian Intern, Pengelolaan Keuangan Daerah dan Komitmen Organisasi terhadap Penerapan Good Governance (Studi Kasus pada Satuan Kerja Perangkat Daerah Kabupaten Tabanan). Jurnal Ilmiah Akuntansi dan Humanika (JINAH). Vol 2. No 1, 2014. Universitas Pendidikan Ganesha. Singaraja

Schermerhorn, Jr. John, R. 1986. Management for Productivity. John Willey \& Sons. New York

Sugiyono 2012. Memahami Peneleitian Kualitatif. ALFABETA. Bandung

Sujarweni, Wiratna. 2015. Akuntansi Sektor Publik. Penerbit Pustaka Baru Press. Yogyakarta 